\title{
The frequency of disseminated intravascular coagulopathy in newly diagnosed adult patients with haematological malignancies attending Nanakaly Hospital in Erbil
}

Accepted: $23 / 7 / 2013$

\begin{tabular}{|c|c|}
\hline . &  \\
\hline \multicolumn{2}{|c|}{ Abstract } \\
\hline \multicolumn{2}{|c|}{$\begin{array}{l}\text { Background and objective: Disseminated intravascular coagulation significantly } \\
\text { contributes to the bleeding and thrombotic complications in patients with haematologic } \\
\text { malignancies. This study was conducted to find out the incidence of disseminated intravas- } \\
\text { cular coagulopathy in haematological malignancies before introduction of chemotherapy. } \\
\text { Methods: A prospective case series study was performed at Nanakaly Hospital for Blood } \\
\text { Diseases from April } 30,2011 \text { to April } 1,2012 \text {. Seventy patients with different } \\
\text { haematological malignancies were enrolled; they were assessed with clinical importance } \\
\text { of global haemostatic laboratory tests. } \\
\text { Results: Eighteen percent of studied patients had overt disseminated intravascular } \\
\text { coagulopathy. The haemostatic measures were higher in overt disseminated intravascular } \\
\text { coagulopathy cases than those with no evidence of disseminated intravascular coagulopa- } \\
\text { thy cases (P < } 0.001) \text {; and the highest incidence of disseminated intravascular coagulopa- } \\
\text { thy cases was in acute promyelocytic leukemia's patients ( } 77 \% \text {, P = 039). Most of dissemi- } \\
\text { nated intravascular coagulopathy cases were clinically manifested with anemia, bleeding } \\
\text { and rarely with thrombosis (100\%, } 69 \% \text { and } 7 \% \text {, respectively). } \\
\text { Conclusion: Disseminated intravascular coagulopathy is not uncommon in haematological } \\
\text { malignancies before starting chemotherapy. Global haemostatic tests are helpful } \\
\text { for diagnosis of disseminated intravascular coagulopathy side by side with clinical } \\
\text { manifestations and medical history. } \\
\text { Keywords: Disseminated intravascular coagulopathy, Haematology malignancies. }\end{array}$} \\
\hline \multicolumn{2}{|l|}{ Introduction } \\
\hline $\begin{array}{l}\text { Disseminated intravascular coagulation } \\
\text { (DIC) is a pathologic syndrome arising } \\
\text { from a heterogeneous group of medical } \\
\text { disorders. It is characterized by laboratory } \\
\text { evidence of consumption and proteolytic } \\
\text { degradation of haemostatic components. } \\
\text { The International Society on Thrombosis } \\
\text { and Haemostasis (ISTH) defines the } \\
\text { pathology of DIC as an "acquired } \\
\text { syndrome characterized by intravascular } \\
\text { activation of coagulation with loss of } \\
\text { localization, which can arise from different } \\
\text { causes, can originate from and cause } \\
\text { damage to the microvasculature and, when } \\
\text { sufficiently severe, can produce organ } \\
\text { dysfunction". } 2 \text { The major pathways that }\end{array}$ & $\begin{array}{l}\text { nt. Such damage is } \\
\text { iated causes of DIC, } \\
\text { arious infections and } \\
\text { ders. } \\
\text { ctivation leading to } \\
\text { nicro-aggregates can } \\
\text { nent of DIC. This is } \\
\text { with some infections } \\
\text { nts with circulating } \\
, 6\end{array}$ \\
\hline
\end{tabular}

* Nanakaly Hospital for Blood Diseases, Directorate of Health, Erbil, Iraq.

** Department of Internal Medicine, College of Medicine, Hawler Medical University, Erbil, Iraq. 
4. Some malignancies, pancreatitis and some snake venoms can directly activate the clotting cascade. ${ }^{7}$

There are differences in the frequency of DIC in haematological malignancies in previously published international articles, as in Ribeiro and Pui, Nur et al, Sarris et al, Higuchi et al, and Dixit et al, ranging from $5-20 \%$. $^{5-8}$

\section{Methods}

This study was conducted in Nanakaly Hospital of Blood Diseases in Erbil governorate. Seventy patients (29 female and 41 male) with their age ranging between 13 -85 years were included in this study. They were attending the hospital whether for consultation or for admission in emergency department. The research included those patients who were above 12 years of age of both genders and newly diagnosed with haematological malignancies that were not treated before and they were screened for the presence of DIC on their first presentation. Patients with haematological malignancies and having received chemotherapy, those with DIC due to nonhaematological malignant diseases, and DIC due to non-haematological and nonmalignant process were excluded. Data were collected by taking information from the patients by both direct interview and using questionnaire that was designed by the researcher. The questionnaire contained variables in the form of patient's demographic information, medical history, examination and investigations including biochemical, haematological with bone marrow and/or lymphoid biopsy. Our cases of DIC were defined according to the guidelines for the diagnosis and management of DIC established by the British Committee for Standards in Haematology (BCSH) taskforce in haemostasis and thrombosis which ascertain screening assays for haemostatic function, such as the prothrombin time (PT), activated partial thromboplastin time (aPTT) or platelet count that provide important evidence of the degree of coagulation factor consumption and activation, in addition, the extent of fibrin formation can be indirectly gauged through measurements of its lysis, through assays such as those that measure fibrin D-dimers. ${ }^{9}$ We also applied the modified International Society on Thrombosis and Haemostasis (ISTH) scoring system (Table 1) for identifying the overt-DIC state among the studied cases with scores more or equal to 5 being compatible with overt DIC. ${ }^{10-13}$ D-Dimer was used instead of fibrinogen degradation products as the later has less sensitivity in many published studies. ${ }^{5,8,14,15}$ Microsoft Office Excel 2007 was used for data entry and SPSS 19 (2010) for analysis of data. Differences between variables were examined for statistical significance by using student's ttest; Levene's test was used to assess the equality of variances. Chi square test was used to test the significance association between different proportions with correction of overestimated chi square value in $2 \times 2$ table by using of Yates continuity correction and Fisher's exact test. ${ }^{16}$

\section{Results}

Among the seventy enrolled cases, 29 cases $(41.4 \%)$ were female with median age $( \pm S D)$ of $38.2( \pm 17.9)$ years and 41 cases $(58.6 \%)$ were male with median age $( \pm S D)$ of $44.1( \pm 20.4)$ years. A thorough investigation concluded that 32 cases $(45.7 \%)$ had Acute Myeloid Leukemia (AML), 10 cases (14.3\%) had Acute Lymphoblastic Leukemia (ALL), 2 cases $(2.9 \%)$ had Chronic Lymphocytic Leukemia (CLL), one case $(1.4 \%)$ had Chronic Prolymphocytic Leukemia (CPL), 2 cases $(2.9 \%)$ had Myeloproliferative Neoplasms (MPN); 1 case with Chronic Myeloid Leukemia and 1 case with Essential Thrombocythemia, 4 cases $(5.7 \%)$ had Myelodysplastic Syndrome (MDS), 3 cases (4.3\%) had Plasma Cell Disorders (PCD); 1 case with Multiple Myeloma and 2 cases with Plasma Cell Leukemia, 2 cases $(2.9 \%)$ had Hairy Cell Leukemia (HCL), 8 cases $(11.4 \%)$ had Non-Hodgkin Lymphoma (NHL); 6 cases of B-cell types and 2 cases of T-cell type, and 6 cases $(8.6 \%)$ of Hodgkin Lymphoma $(\mathrm{HL}) ; 3$ cases for mixed cellularity type and 
3 cases for nodular sclerosis type(Table 2 ). According to modified ISTH scoring system, 13 patients $(18.6 \%)$ were diagnosed as overt-DIC cases with mean score of 5.7 (SD: $\pm 0.94, \mathrm{Cl}: 5.1-6.3$ ) ranging between $5-8$ and mean age of $(46.8 \pm 20$ years) in which 9 cases were male and 4 cases were female. Twelve of these overt-DIC cases were AML (10 cases APL, 1 case AML M4 and 1 case AML M5), the AML cases were classified according to French-AmericanBritish (FAB) classification, with one case of T-cell NHL, Table 3. All patients with overt DIC were presented with anemia with mean hemoglobin level of $8 . \pm 1.2 \mathrm{~g} / \mathrm{dl}$. Other clinical features were bleeding tendency like skin manifestations (ecchymoses, petechiae, and purpura), haematuria, epistaxis, vaginal bleeding and gastrointestinal and only one case presented with deep venous thrombosis of lower limb, Table 4. Patients with overt-DIC had significant changes in their haemostatic parameters in comparison to non-DIC cases (Table 5). Among the 70 studied cases, those patients with APL (17.1\%) showed significant changes in the haemostatic parameter from those with non-APL $(82.9 \%)$ as it is illustrated in Table 6. Among 32 AML cases, there was significant difference between APL cases (12 cases $-37.5 \%$ ) and non-APL cases (20 cases $-62.5 \%)$ in ISTH scores and diagnostic criteria of DIC (Table 7). Although NHL patients with overt-DIC were infrequent in this study and only one case was reported; but there was significant difference in the coagulation studies between this case and cases of AML. Interestingly there was no case of overt-DIC among ten ALL patients, also no overt-DIC has been reported among CLL, CPL, MPN, MDS, PCD, MM and $\mathrm{HCL}$ patients. There was no significant difference in the haemostatic parameters between the genders among overt-DIC cases (Table 8).

Table 1: The modified ISTH scoring system for overt DIC

1. Presence of an underlying disorder known to be associated with DIC

If yes, proceed. If no, do not use this algorithm.

2. Score global coagulation test results

Platelet count $(>100=0 ;<100=1 ;<50=2)$

Level of fibrin markers (soluble fibrin monomers/fibrin degradation products)

(no increase: 0; moderate increase: 2; strong increase: 3 )

Prolonged prothrombin time $(<3 \mathrm{~s} .=0 ;>3 \mathrm{~s}$. but $<6 \mathrm{~s} .=1 ;>6 \mathrm{~s}=2)$

Fibrinogen level $\quad(>1.0 \mathrm{~g} / \mathrm{L}=0 ;<1.0 \mathrm{~g} / \mathrm{L}=1)$

\section{Calculate score}

4. If more or equal to 5: compatible with overt DIC; repeat scoring daily If <5: suggestive (not affirmative) for non-overt DIC; repeat next 1-2 days 
The frequency of disseminated intravascular .......

Table 2: The frequency of haematology malignant cases in current research.

\begin{tabular}{lll}
\hline Haematolgy Malignancies & Frequency & $\%$ \\
\hline AML (acute myeloblastic leukemia) & 32 & 45.7 \\
ALL (acute lymphoblastic leukemia) & 10 & 14.3 \\
MDS( myelodysplastic syndromes) & 4 & 5.7 \\
MPN (myeloproliferative neoplasms) & 2 & 2.8 \\
PCD (plasma cell dyscrasias) & 3 & 4.3 \\
CLL/PL (chronic lymphocytic leukemia/ & 3 & 4.3 \\
prolymphocytic leukemia) & 2 & 2.8 \\
HCL (hairy cell leukemia) & 6 & 8.6 \\
HL (Hodgkin lymphoma) & 8 & 11.5 \\
NHL (non-Hodgkin lymphoma) & 70 & 100 \\
Total & & \\
\hline
\end{tabular}

Table 3: Frequency of overt-DIC among the studied cases.

\begin{tabular}{llll}
\hline Haematology Malignancies & $\mathbf{N}$ & Frequency (\%) & $\boldsymbol{P}$ value \\
\hline AML M3 & 10 & 77 & \\
AML M4 & 1 & 7.7 & \\
AML M5 & 1 & 7.7 & \\
NHL T-cell & 1 & 7.7 & \\
Total & 13 & & \\
\hline
\end{tabular}

Table 4: Signs and symptoms of overt DIC patients.

\begin{tabular}{lll}
\hline Chief of complain & Frequency & (\%) \\
\hline Anemia & 13 & 100 \\
Fever & 7 & 54 \\
Renal involvement & 5 & 38 \\
Bleeding & 5 & 38 \\
Skin involvement & 5 & 38 \\
Respiratory involvement & 5 & 38 \\
Jaundice & 4 & 30 \\
Shock & 2 & 15 \\
Thrombosis & 1 & 7 \\
\hline
\end{tabular}


Table 5: Comparison between overt-DIC and non-DIC cases.

\begin{tabular}{llllll}
\hline & \multicolumn{2}{l}{ Non- DIC $(\boldsymbol{n}=\mathbf{5 7})$} & \multicolumn{2}{l}{ Overt DIC $(\boldsymbol{n}=\mathbf{1 3})$} & \\
& Mean & SD & Mean & SD & $\boldsymbol{P}$ value $^{*}$ \\
\hline ISTH Score & 2 & 1 & 6 & 1 & $<0.001$ \\
PT $(\mathrm{sec})$ & 16.2 & 2.9 & 20.2 & 2.7 & $<0.001$ \\
PTT $(\mathrm{sec})$ & 25.5 & 4.4 & 43.9 & 6.1 & $<0.001$ \\
BT $(\mathrm{min})$ & 5.6 & 2.4 & 8.7 & 2.02 & $<0.001$ \\
Platelet $\left(\times 10^{9} / \mathrm{l}\right)$ & 149511 & 157879 & 45308 & 30118 & $<0.001$ \\
Fibrinogen $(\mathrm{mg} / \mathrm{dl})$ & 334 & 90 & 134 & 55 & $<0.001$ \\
D-Dimer $(\mathrm{ng} / \mathrm{ml})$ & 599 & 1462 & 3834 & 2419 & $<0.001$ \\
\hline
\end{tabular}

* An independent-sample t-test was used (Levene's test for assessment of equality of variance was used).

Table 6: The comparison between APL and non-APL cases among the (70) recruited cases.

\begin{tabular}{llllll}
\hline & \multicolumn{2}{l}{ non-APL $(\boldsymbol{n}=\mathbf{5 8})$} & \multicolumn{2}{l}{ APL $(\boldsymbol{n}=\mathbf{1 2})$} & \\
& Mean & SD & Mean & SD & $\boldsymbol{p}$ value* \\
\hline ISTH Score & 2 & 2 & 6 & 1 & $<0.001$ \\
D-Dimer $(\mathrm{ng} / \mathrm{ml})$ & 594 & 1309 & 4127 & 2679 & 0.001 \\
Fibrinogen $(\mathrm{mg} / \mathrm{dl})$ & 324 & 94 & 169 & 128 & $<\mathbf{0 . 0 0 1}$ \\
PTT $(\mathrm{sec})$ & 26.5 & 5.7 & 41.0 & 10.4 & 0.001 \\
PT $(\mathrm{sec})$ & 16.5 & 3.3 & 18.8 & 2.3 & 0.026 \\
BT $(\mathrm{min})$ & 5.7 & 2.5 & 8.4 & 2.1 & 0.01 \\
Platelet $\left(\times 10^{9} / \mathrm{l}\right)$ & 147433 & 157509 & 46667 & 24463 & $<\mathbf{0 . 0 0 1}$ \\
\hline
\end{tabular}

${ }^{*}$ An independent-sample t-test was used (Levene's test for assessment of equality of variance was used).

Table 7: Comparison between APL and non-APL haemostatic parameters among AML cases.

\begin{tabular}{llllll}
\hline & \multicolumn{2}{l}{ non-APL $(\boldsymbol{n}=\mathbf{2 0})$} & \multicolumn{2}{l}{ APL $(\boldsymbol{n}=\mathbf{1 2})$} & \\
& Mean & SD & Mean & SD & $\boldsymbol{P}$ value \\
\hline ISTH Score & 3 & 2 & 5 & 1 & $<0.001$ \\
D-Dimer $(\mathrm{ng} / \mathrm{ml})$ & 1249 & 2045 & 4127 & 2679 & 0.005 \\
Fibrinogen $(\mathrm{mg} / \mathrm{dl})$ & 274 & 95 & 169 & 128 & 0.012 \\
PT $(\mathrm{sec})$ & 16.9 & 3.1 & 18.8 & 2.3 & 0.07 \\
PTT $(\mathrm{sec})$ & 28.6 & 6.0 & 41.0 & 10.4 & $<0.001$ \\
BT $(\mathrm{min})$ & $7 / 05$ & 2.4 & 8.4 & 2.05 & 0.1 \\
Platelet $\left(\times 10^{9} / \mathrm{l}\right)$ & 71600 & 64414 & 46667 & 24463 & 0.21 \\
\hline
\end{tabular}

* Independent student's t-test was used with Levene's test for assessment of variance equality. 
Table 8: The haemostatic laboratory results between genders in overt-DIC cases.

\begin{tabular}{|c|c|c|c|c|c|}
\hline & \multicolumn{5}{|c|}{ Overt DIC cases } \\
\hline & \multicolumn{2}{|c|}{ Female $(n=4)$} & \multicolumn{2}{|c|}{ Male $(n=9)$} & \multirow[b]{2}{*}{$P$ value } \\
\hline & Mean & SD & Mean & SD & \\
\hline ISTH Score & 6 & 1 & 6 & 1 & 0.45 \\
\hline PT (sec) & 19.3 & 1.3 & 20.6 & 3.1 & 0.44 \\
\hline PTT (sec) & 43.0 & $9 . .8$ & 44.3 & 4.4 & 0.29 \\
\hline BT (min) & 9.1 & 0.6 & 8.5 & 2.4 & 0.65 \\
\hline Platelet $\left(\times 10^{9} / \mathrm{I}\right)$ & 39250 & 25552 & 48000 & 33004 & 0.52 \\
\hline Fibrinogen (mg/dl) & 100 & 8 & 149 & 60 & 0.13 \\
\hline D-Dimer (ng/ml) & 3500 & 2376 & 3982 & 2565 & 0.75 \\
\hline
\end{tabular}

An independent-sample t-test (Levene's test for equality of variances) was used.

\section{Discussion}

The current study showed that 13 cases of $70(18.5 \%)$ presented with overt-DIC depending on guidelines for the diagnosis and management of disseminated intravascular coagulation established by the British Committee for Standards in Haematology (BCSH) taskforce in haemostasis and thrombosis. In comparison to other published data, the incidence of overt-DIC in this case series study had no significant difference. Dixit et $\mathrm{al}^{5}$ showed $14.9 \%$ incidence of overt-DIC in 67 patients with acute leukemia on presentation. Higuchi et al ${ }^{8}$ showed that $16 \%$ had overt-DIC cases and Nur et $\mathrm{al}^{6}$ found $13.4 \%$ of their patients had overt-DIC in their presentation. Although majority of our diagnosed cases of overt-DIC (93\%) were found in age more than 18 years and higher incidence in male $(70 \%)$ but current study did not find any association of occurrence of DIC with age of patients and gender. These observations agree with Dixit et al and Nur et al. ${ }^{5,6}$ All patients with overt-DIC presented with anemia and majority (69\%) of them had bleeding, while thrombosis was rare and occurred in one patient only. The bleeding manifestations was significantly higher among APL patients in contrast to non-APL patients $(42 \%$ vs. $13.8 \%, p=0.032)$, the finding that could $x$ be related to high incidence of DIC in APL patients in comparison to non-APL patients. In addition, high prevalence of thrombotic event was seen in APL than non-APL cases that could be secondary to hyperfibrinolysis and consequent fibrin deposition and clot formation., 12,17,18 Also there were significant bleeding manifestations in patients with DIC in comparison to non-overt DIC patients $(p=0.037)$ this influences the importance of early detection of DIC in haematological malignancies to minimize the bleeding manifestations. The majority of overt-DIC in our study occurred in AML patients $(93 \%)$ with significantly higher changes in their global haemostatic measures than non-AML patients $(p=0.04)$. Dixit et $\mathrm{al}^{5}$ disclosed that $40 \%$ of diagnosed overt-DIC cases were AML patients and $60.4 \%$ of DIC cases in Nur et $\mathrm{al}^{6}$ were AML. This difference in the occurrence of DIC among subtypes of leukemia may be related to the differences in the incidence of leukemia subtypes from one place to other. ${ }^{19}$ There are no doubts that APL among AML subtypes had higher rate of incidence of DIC (50-95\%) in published articles, $2,10,11,16$ the fact that our study showed more than $75 \%$ of diagnosed cases of overt-DIC in patients with APL. There was no any case of DIC in ALL patient groups in current 
study; the coagulation parameters were significantly higher in patients of AML than ALL. This can be explained by the difference in biological components between myeloblast and lymphoblast as myeloblast has higher level of cancer procoagulant in addition to higher incidence of abnormal coagulation studies in APL subtype of AML. ${ }^{1,2,8,19}$ Although majority of studies did not concern about the incidence of DIC in the lymphoma patients, the current study did find a case of overt-DIC in patient with stage IV T-cell type NHL, the finding that was reported in a Japanese study which showed significant incidence of DIC in advance stages of NHL. ${ }^{2}$ This signifies that other haematological malignancies should not be underestimated in screening for DIC at presentation. This study as well as other published articles showed that DIC is rare or even not recorded in other haematological malignancies like MPN, MDS, CLL/PL, PCD, and HCL ${ }^{13,16}$ Overt-DIC cases in current study showed ISTH score average of 5.7 on their presentations, the average of the parameters were: PT (20.2 sec), D-Dimer (3834 $\mathrm{ng} / \mathrm{dl})$, serum fibrinogen $(134 \mathrm{mg} / \mathrm{dl})$ and platelet counts of $(45308 \mathrm{cells} / \mathrm{ml})$. These changes were found to be significantly higher in overt-DIC than in non-overt DIC patients $(P \leq 0.001)$. There was considerable inverse correlation between ISTH score and $\mathrm{Hb}$ level $(r=-0.29, p=0.018)$, the finding that had not been found in previous studies. $^{10-12}$ This may explain that our diagnosed patient with DIC were almost all presented with anemia which could be related to high burden of malignancy or on the other hand may be related to occult bleeding secondary to thrombocytopenia or DIC by itself. ${ }^{2}$ As in other studies we observe a significant correlation of DIC occurrence and elevation of PTT $(r=0.71$, $\mathrm{P}<0.001)^{2,10,12,20}$ These may collectively influence the revision of ISTH score system for adding aPTT and BT in their criteria.

\section{Conclusion}

DIC is not uncommon complication in haematological malignant disorders before induction of chemotherapy. Among patients with haematological malignancies, AML has higher incidence of DIC and the highest incidence was in APL (AML-M3). Anemia and bleeding manifestations are more common than thrombotic features. The diagnosis of overt-DIC needs a correlation between lab investigations and clinical examination.

\section{Conflicts of interest}

The authors report no conflicts of interest.

\section{References}

1. Hoffman R. Haematology, Basic Principles and Practice. $5^{\text {th }}$ ed. Netherlands: Elsevier; 2011.

2. Franchini M, Di Minno M. DIC in Haematological Malignancies. Semin Thromb Hemost 2010; 36:388-403.

3. Gomez K, Tuddenham E, McVey J. Normal Haemostasis. In: Hoffbrand A, Catovsky D, Green A. Postgraduate Haematology. $6^{\text {th }}$ ed. New Jersey: Wiley-Blackwell; 2011.

4. Manning $R$, Laffan $M A$. Investigation of haemostasis. In: Bain B J, Bates I, Laffan M A. Dacie and Lewis Practical Haematology. $11^{\text {th }}$ ed. Netherlands: Elsevier; 2011.P. 409-10.

5. Dixit A, Chatterjee T, Mishra P, Kannan M. Disseminated Intravascular Coagulation in Acute Leukemia at Presentation and During Induction Therapy. Clin Appl Thromb Hemost 2007; 13: 292.

6. Nur S, Anwar M, Saleem M, Ahmad PA. DIC in acute leukaemias at first diagnosis. Eur $\mathrm{J}$ Haematol 1995; 55: 78-82.

7. Rodgers G. Acquired Coagulation Disorders. In: John P G, John F. Wintrobe's Clinical Haematology. $12^{\text {th }}$ ed. Philadelphia: Lippincott Williams \& Wilkins; 2009. P. 1430-1.

8. Higuchi T, Toyama D, Hirota Y. DIC complicating acute lymphoblastic leukemia: A study of childhood and adult cases. Leuk Lymphoma 2005; 46(8): $1169-76$.

9. Levi M, Toh $\mathrm{CH}$, Thachil J, Watson HG. Guidelines for the diagnosis and management of disseminated intravascular coagulation. $\mathrm{Br} J$ Haematol 2009; 145 (1): 24-33.

10. Taylor FB, Toh CH, Hoots WK, Wada H, Levi M. Scientific Subcommittee on DIC of the ISTH, Towards definition, clinical and laboratory criteria, and a scoring system for disseminated intravascular coagulation. Thromb Haemost 2001; 86 (5):1327-30.

11. Collins $P$, Thachi J, Toh $C$. Acquired Coagulation Disorders. In: Hoffbrand A, Catovsky D, Green A. Postgraduate Haematology. $6^{\text {th }}$ ed. New Jersey: Wiley-Blackwell; 2011. 
12. Iba T, Asakura H. Comparison between British and Japanese guidelines for the diagnosis and treatment of DIC. $\mathrm{Br} \mathrm{J}$ Haematol 2010; 149:451-62.

13. Toh C, Hoots W. The scoring system of the Scientific and Standardization Committee on DIC of the ISTH: a 5-year overview. Thromb Haemost 2006; 5: 604-6.

14. Bakhtiari K, Meijers JC, de Jonge E, Levi M. Prospective validation of the ISTH scoring system for DIC. Crit Care Med. 2004; 32(12):2416-21.

15. Wada $H$, Sakuragawa N. Are fibrin-related markers useful for the diagnosis of thrombosis? Semin Thromb Hemost 2008; 34(1):33-8.

16. Pallant J. SPSS Survival Manual - A Step by Step Guide to Data Analysis Using SPSS for Windows. 3rd ed. New York: McGraw-Hill; 2007.

17. Sharma P, Saxena R. Limited Utility of a Rapid Quantitative Enzyme-Linked Fluorescent Assay for the D-Dimer in the Diagnosis of Overt DIC. Clin Appl Thromb Hemost 2010; 16: 609-13.

18. Kaushansky K, Lichtman M. William's Haematology. $8^{\text {th }}$ ed. New York: McGraw-Hill; 2010.

19. Hoelzer D, Gökbuget N. Acute Lymphocytic Leukemia in Adults. In: Hoffman R. Haematology, Basic Principles and Practice. $5^{\text {th }}$ ed. Netherlands: Elsevier; 2011.

20. Favaloro E. Laboratory Testing in DIC. Semin Thromb Hemost 2010; 36:458-68. 